\title{
Watershed Scale Response to Climate Change-Trout Lake Basin, Wisconsin
}

\section{Introduction}

General Circulation Model (GCM) simulations of future climate through 2099 project a wide range of possible scenarios (Intergovernmental Panel on Climate Change, 2007). To determine the sensitivity and potential effect of long-term climate change on the freshwater resources of the United States, the U.S. Geological Survey Global Change study, "An integrated watershed scale response to global change in selected basins across the United States" was started in 2008. The long-term goal of this national study is to provide the foundation for hydrologically based climate-change studies across the nation

Fourteen basins for which the Precipitation Runoff Modeling System (PRMS) has been calibrated and evaluated were selected as study sites. PRMS is a deterministic, distributedparameter watershed model developed to evaluate the effects of various combinations of precipitation, temperature, and land use on streamflow and general basin hydrology. Output from five GCMs and four emission scenarios were used to develop an ensemble of climate-change scenarios for each basin. These ensembles were simulated with the corresponding PRMS model. This fact sheet summarizes the hydrologic effect and sensitivity of the PRMS simulations to climate change for the Trout River Basin at Trout Lake in northern Wisconsin (U.S. Geological Survey streamflow-gaging station 05357245; fig. 1) presented in the project summary report (Markstrom and others, 2012) and a journal article (Hay and others, 2011).

\section{Study Area}

The Trout Lake Basin is located in the Northern Highlands district in north central Wisconsin, in an area with many lakes. The aquifer consists of 40-60 meters (m) of unconsolidated Pleistocene glacial sediments mostly comprised of glacial outwash sands and gravel. In this area, streamflow is dominated by contributions from groundwater; however, surface runoff can occur during intense rainfall periods and spring snowmelt. Surface runoff also occurs locally in low-lying areas near streams and lakes where the unsaturated zone is thin. The Trout Lake Basin (which includes Trout Lake and all four of the basins that flow into the lake) has been the focus of previous regional groundwater modeling studies including a two-dimensional analytic element screening model and three-dimensional, finitedifference models. See Walker and Bullen (2000) for additional descriptions of the setting and Pint (2002) and Hunt and others (2005; 2008) for more description of previous modeling efforts.

The Trout Lake Basin is one of five research watersheds in the U.S. Geological Survey's Water, Energy and Biogeochemical Budgets (WEBB) program, and is collocated with the National Science Foundation funded North Temperate Lakes Long Term Ecological Research site (Magnuson and others, 1984). A major focus of the Trout Lake WEBB project is the development of a watershed model to allow predictions of hydrologic and biogeochemical responses to future conditions including land-use and climate change. 


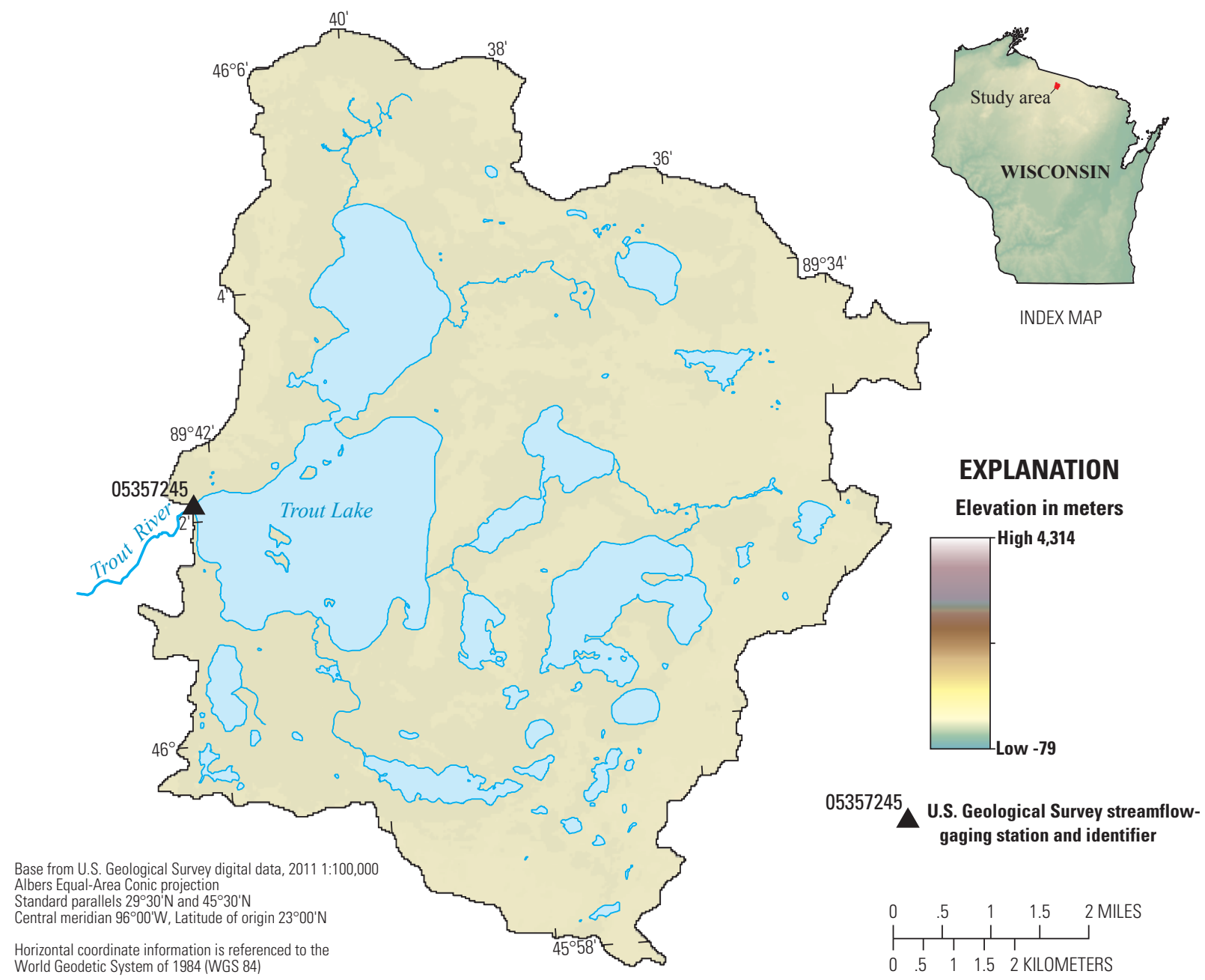

Figure 1. Precipitation Runoff Modeling System study locations, Trout River Basin, Wisconsin, and location of U.S. Geological Survey streamflow-gaging station 05357245 with a drainage area of 120 square kilometers and elevation range from 491 to 522 meters.

\section{General Circulation Models}

Given the uncertainty in climate modeling, it is desirable to use more than one GCM to obtain a range of potential future climatic conditions. Monthly precipitation and temperature output from five GCMs were processed (table 1).

Table 1. General Circulation Model (GCM) projections used in this study.

\begin{tabular}{cl}
\hline \multicolumn{1}{c}{ GCM } & \multicolumn{1}{c}{ Center and country of origin } \\
\hline BCC-BCM2.0 & Bjerknes Centre for Climate Research, Norway \\
CSIRO-Mk3.0 & Australia's Commonwealth Scientific and Industrial Research Organization, Australia \\
CSIRO-Mk3.5 & Australia's Commonwealth Scientific and Industrial Research Organization, Australia \\
INM-CM3.0 & Institute for Numerical Mathematics, Russia \\
\hline
\end{tabular}


The GCM outputs were obtained from the World Climate Research Programme's Coupled Model Intercomparison Project phase 3 multi-model dataset archive, which was referenced in the Intergovernmental Panel on Climate Change Fourth Assessment Special Report on Emission scenarios (Intergovernmental Panel on Climate Change, 2007). For each GCM, one current (water years 1988-1999) and three future emission scenarios were used and are described in table 2.

Table 2. Climate-change emission scenarios simulated by the General Circulation Models in this study.

\begin{tabular}{ll}
\hline \multicolumn{1}{c}{ Emission scenario } & \multicolumn{1}{c}{ Description/assumptions } \\
\hline 20C3M & $\begin{array}{l}\text { 20th century climate used to determine baseline (1989-1999) conditions } \\
\text { Rapid economic growth, a global population that peaks in mid-21st century and rapid introduction of new and } \\
\text { more efficient technologies with a balanced emphasis on all energy sources } \\
\text { A1B }\end{array}$ \\
B1 & $\begin{array}{l}\text { envergent world, with the same global population as Emission scenario A1B, but with more rapid changes in } \\
\text { econic structures toward a service and information economy that is more ecologically friendly }\end{array}$ \\
A2 & Heterogeneous world with high population growth, slow economic development, and slow technological change \\
\hline
\end{tabular}

Climate-change fields were derived by calculating the change in climate from current (water years 1988-1999) to future conditions simulated by each GCM. The 20C3M simulation for water years 1988-1999 was used to represent current climatic conditions. This 12-year period of record was chosen based on the overlap of the available historical records from the 14 basins included in the national study. Climate change fields (percentage changes in precipitation and degree changes in temperature) were computed for 12-year moving window periods (from 2001-2099) using the 20C3M (1988-1999) and the A1B, B1, and A2 emission scenarios. A 12-year moving window, starting in 2001 and ending in 2099, results in 1,320 future scenarios $[(88,12$-year climatologies, 1 per year starting with 2001-2012 and ending with 2088-2099) x (3 emission scenarios) $\mathrm{x}(5 \mathrm{GCMs})]$.

Climate-change scenarios were generated for PRMS by modifying PRMS precipitation and temperature inputs with the mean monthly climate change fields derived from the GCMs, resulting in 1,320 PRMS-input files. Table 3 shows the change (slope) and adjusted $\mathrm{R}^{2}$ (adjR2) for the least squares fit to the trend line for selected output variables from the PRMS projections. The slope indicates the change in the selected variable by year. The adjusted $\mathrm{R}^{2}$ value gives an indication of the variability in the central tendency of the trend line.

Figure 2 shows a summary of the projected range in 11-year moving mean daily values of maximum temperature (fig. $2 A$ ), minimum temperature (fig. $2 B$ ), and precipitation (fig. $2 C$ ) by emission scenario. The first year of each 12-year simulation was used as PRMS initialization and is not included in the results. The three solid-colored lines indicate the 11-year moving mean values (x-axis indicates center of 11-year window) for the three future emission scenarios (central tendency of the five GCMs for each emission scenario). The projected range shown for each emission scenario indicates the range of potential future climatic conditions simulated by the five GCMs. All GCM simulations project an overall increase in maximum and minimum temperature (table 3), with uncertainties associated with these GCM projections increasing with time. Both maximum and minimum temperatures show the smallest projected changes for the B1 emission scenario. Projections of precipitation are highly variable, with the range in projections showing both increases and decreases. The wide range and lack of significant trend in the precipitation projections indicate a large amount of uncertainty in the GCM emission scenarios used in this study (table 3).

\section{Results}

PRMS simulates spatially distributed streamflow, components of flow (surface, subsurface, and groundwater), snowpack conditions, and many other hydrologic components of interest including soil moisture. Projected changes in the fraction of precipitation that falls as snow, snow-covered area, and snowmelt were examined on a monthly basis (figs. $3 A-3 C$ ). The solid-red lines in figure 3 show PRMS-simulated mean monthly baseline conditions (1989-1999) for the three snow components. The plots represent the range in the mean monthly projections for the five GCMs and three emission scenarios for 2030 (green, 2025-2035), 2060 (tan, 2055-2065) and 2090 (blue, 2085-2095). Across nearly all months there is a dramatic shift towards a smaller fraction of precipitation falling as snow, and a corresponding decrease in snow-covered area throughout all of the winter months. During the traditional snowmelt season there is a noticeable projected decrease in the late season snowmelt (April and May) with smaller increases in snowmelt earlier in the winter.

Changes in groundwater recharge were examined on an annual and monthly basis (figs. 4 and 5). The results across the GCMs and emissions scenarios are highly variable, projecting no overall significant trend in mean annual groundwater recharge (fig. 4, table 3). For baseline conditions, recharge is dominated by the spring snowmelt; based on the results in figure 5 , the seasonal distribution of recharge will flatten out. This will reduce the importance of spring snowmelt and increase the occurrence of smaller recharge events occurrences throughout the year.

Intermediate states of interest produced by PRMS are summarized in the complete project report (Markstrom and others, 2011). Figure 6 shows a summary of PRMS-simulated basin mean annual values of soil moisture for the three emission 

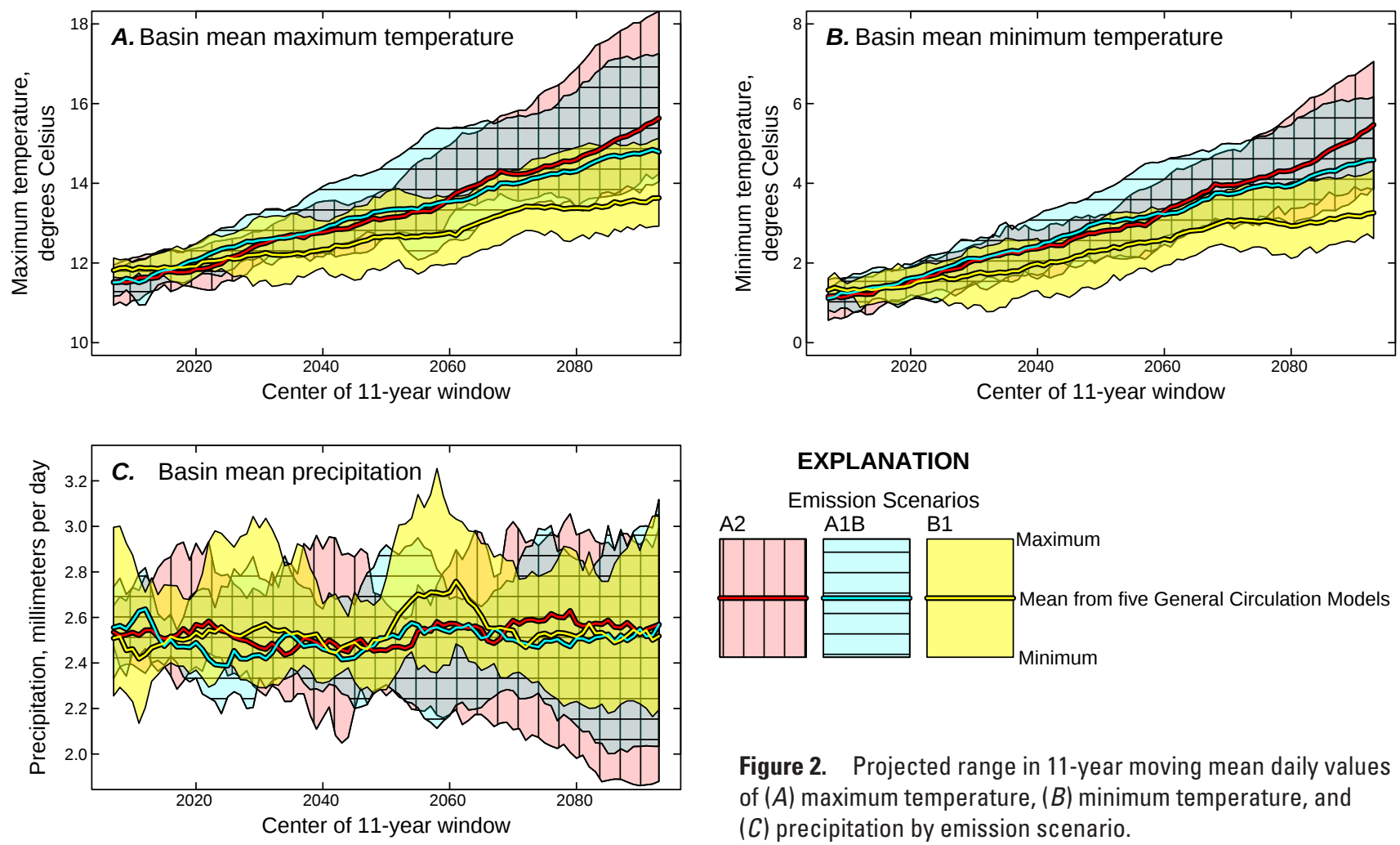

Figure 2. Projected range in 11-year moving mean daily values of $(A)$ maximum temperature, $(B)$ minimum temperature, and (C) precipitation by emission scenario.

Table 3. Projected change by year (slope) and adjusted $R^{2}$ (adjR2) based on the central tendencies of the five General Circulation Models for the three carbon emission scenarios for selected Precipitation Runoff Modeling System (PRMS)output variables.

[Blue indicates a significant negative trend and yellow indicates a significant positive trend $(\mathrm{p}<0.05)$ accounting for lag- 1 autocorrelation]

\begin{tabular}{|c|c|c|c|c|c|c|}
\hline \multirow{2}{*}{ PRMS output variable } & \multicolumn{2}{|c|}{$\begin{array}{c}\text { Emission scenario } \\
\text { A1B }\end{array}$} & \multicolumn{2}{|c|}{$\begin{array}{c}\text { Emission scenario } \\
\text { A2 }\end{array}$} & \multicolumn{2}{|c|}{$\begin{array}{c}\text { Emission scenario } \\
\text { B1 }\end{array}$} \\
\hline & Slope & adjR2 & Slope & adjR2 & Slope & adjR2 \\
\hline Maximum temperature in degrees Celsius & 0.039 & 0.99 & 0.047 & 0.99 & 0.023 & 0.97 \\
\hline Minimum temperature in degrees Celsius & 0.041 & 1.00 & 0.048 & 0.99 & 0.026 & 0.97 \\
\hline Precipitation in millimeters per day & 0.0004 & 0.02 & 0.0008 & 0.20 & 0.0007 & 0.05 \\
\hline Percent snow in percent per day & -0.06 & 0.92 & -0.06 & 0.92 & -0.04 & 0.72 \\
\hline Snow-covered area in percent per day & -0.12 & 0.98 & -0.13 & 0.98 & -0.08 & 0.90 \\
\hline Snowmelt in millimeters per day & -0.0012 & 0.80 & -0.0014 & 0.77 & -0.0009 & 0.61 \\
\hline Groundwater recharge in millimeters per day & -0.0028 & 0.38 & -0.0025 & 0.44 & -0.0011 & 0.04 \\
\hline Soil moisture in millimeters per day & -0.0217 & 0.95 & -0.0227 & 0.97 & -0.0106 & 0.67 \\
\hline
\end{tabular}

scenarios. The central tendencies of the five GCMs for each of the three emission scenarios shows a significant decrease over time (table 3), indicating an overall drying of the soil zone where plant roots reside. Further, as the simulations progress throughout the 21 st century, the uncertainty surrounding the model predictions increases considerably. How the plant community and related evapotranspiration rates might change in response to this change in soil moisture is a topic of on-going work. Ongoing work includes possible changes in plant community and related evapotranspiration rates in response to change in soil moisture. 

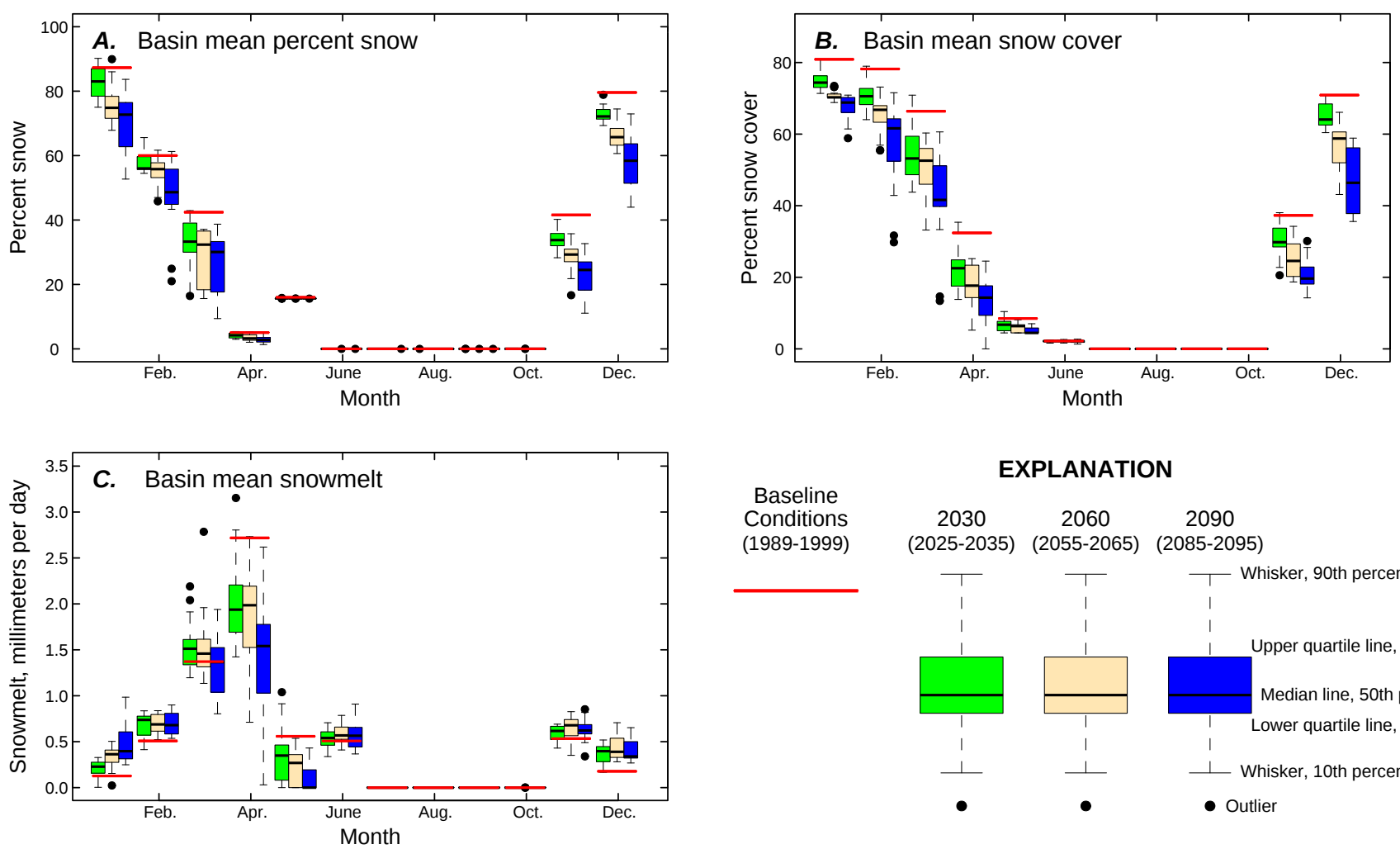

$\begin{array}{lccc}\text { Conditions } & 2030 & 2060 & 2090 \\ (1989-1999) & (2025-2035) & (2055-2065) & (2085-2095)\end{array}$

Figure 3. Mean daily $(A)$ precipitation that falls as snow, $(B)$ snow-covered area, and $(C)$ snowmelt values by month for baseline conditions and projected range $(2030,2060$, and 2090) using the five General Circulation Models and three emission scenarios.

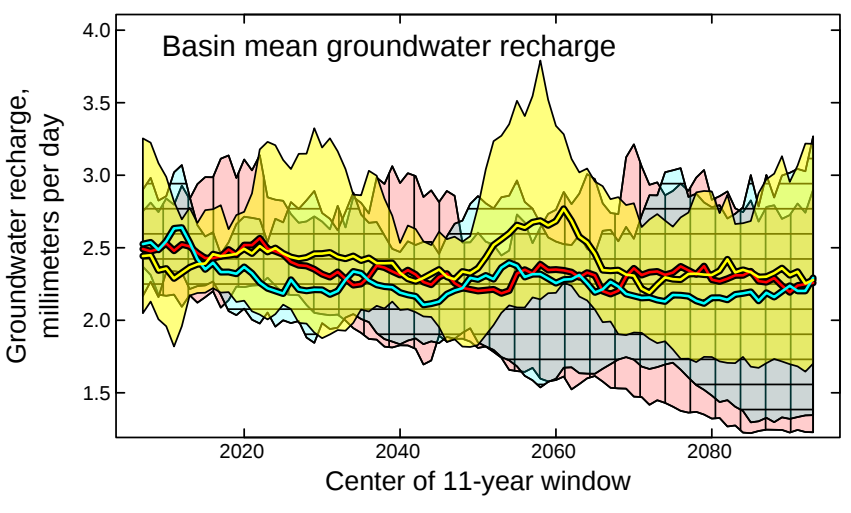

Figure 4. Projected range in 11-year moving mean daily values of groundwater recharge by emission scenario.

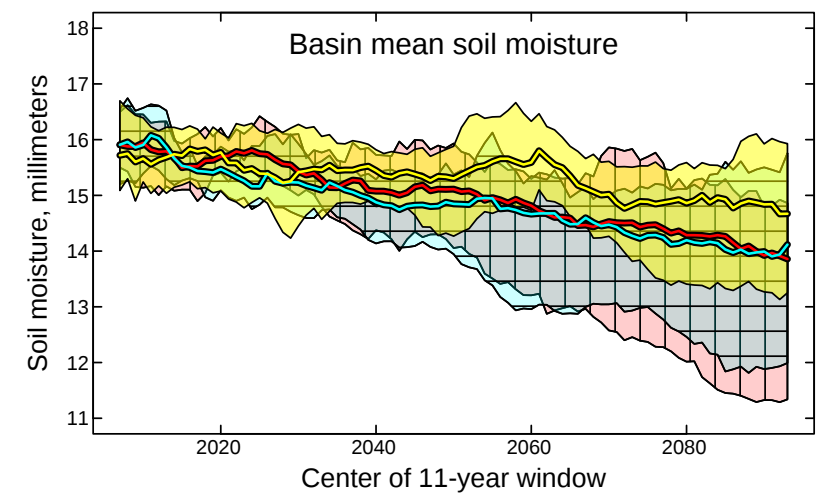

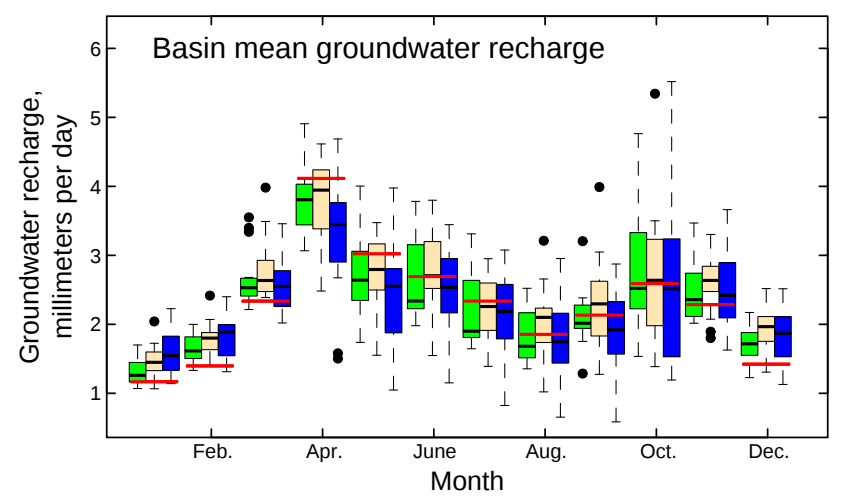

Figure 5. Mean daily groundwater recharge values by month for baseline conditions and projected range (2030, 2060, and 2090) using the five General Circulation Models and three emission scenarios.

\section{EXPLANATION}

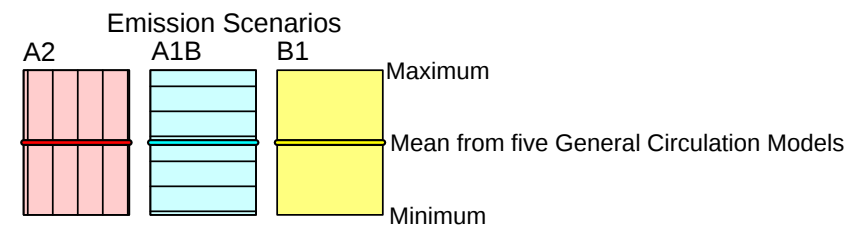

Figure 6. Projected range in 11-year moving mean daily values of soil moisture by emission scenario. 


\section{.}

\section{Conclusion and Discussion}

The snow-component results in the Trout Lake Basin indicate a shorter snow-covered season, with smaller snowpack volumes and a tendency for mid-winter melts. This has implications for winter recreation, and potentially could potentially affect phenological responses, with corresponding changes in the ecosystem. The groundwater-recharge results indicate a shift in the timing of recharge resulting in a flattening of the seasonal recharge response, with more prominent recharge pulses during the growing season and late fall. This change potentially could affect the seasonal nature of water budgets to lakes and the seasonal distribution of streamflow, which both depend on groundwater levels. As with the snow-component response, a shift in the timing of groundwater-recharge could alter phenological responses with associated ecosystem changes.

The soil-moisture results indicate a reduction of soil moisture, which potentially could change the overall vegetation in the system. This has obvious ecosystem implications and potentially could result in an altered less diverse plant assemblage. Furthermore, the system likely would be increasingly prone to fires. A fire occurrence event dramatically would alter the hydrologic response after a fire event occurrence.

One of the principle concerns in the Trout Lake area is the fates of hydrologic budgets of area lakes and resulting lake levels. This has wide ranging implications for property values, recreational use of the lakes, the hard-water/soft-water status and trophic state of the lakes, and the biotic response within the lakes. A more sophisticated representation of the groundwater system likely would provide a more complete view of the response of the basin hydrology to change. A coupled groundwater-surface water model (GSFLOW; Markstrom and others, 2008) can predict the response of the full hydrologic system, including groundwater and lake levels. This will in turn allow a more complete assessment of the response of the system to climate and land land-use change.

\section{By John F. Walker, Randall J. Hunt, Lauren E. Hay, and Steven L. Markstrom}

For more information visit the following Web sites:

http://wwwbrr.cr.usgs.gov/projects/SW_MoWS/

http://infotrek.er.usgs.gov/doc/webb/

http://wi.water.usgs.gov/

http://www.usgs.gov/climate_landuse/

\section{Selected References}

Hay, L.E., Markstrom, S.L., and Ward-Garrison, C.D., 2011, Watershed-scale response to climate change through the twenty-first century for selected basins across the United States, Earth Interactions, v. 15, 37 p.

Hunt, R.J., Feinstein, D.T., Pint, C.D., and Anderson, M.P., 2005, The importance of diverse data types to calibrate a watershed model of the Trout Lake Basin, northern Wisconsin: Journal of Hydrology, v. 321, p. 286-296.

Hunt, R.J., Prudic, D.E., Walker, J.F., and Anderson, M.P., 2008, Importance of unsaturated zone flow for simulating recharge in a humid climate: Ground Water, v. 46, no. 4, p. 551-560.

Intergovernmental Panel on Climate Change, 2007, Summary for policymakers, in Climate change 2007-The physical science basis, Contributions of Working Group 1 to the Fourth Assessment Report of the Intergovernmental Panel on Climate Change: Cambridge and New York, Cambridge University Press, $18 \mathrm{p}$.

Magnuson, J.J., Bowser, C.J., and Kratz, T.K., 1984, Long-term ecological research (LTER) on north temperate lakes of the United States: Internationale Vereinigung fuer Theoretische und Angewandte Limnologie Verhandlungen, v. 22, no. 1, p. 533-535.

Markstrom, S.L., Hay, L.E., Ward-Garrison, C.D., Risley, J.C., Battaglin, W.A., Bjerklie, D.M., Chase, K.J., Christiansen, D.E., Dudley, R.W., Hunt, R.J., Koczot, K.M., Mastin, M.C., Regan, R.S., Viger, R.J., Vining, K.C., and Walker, J.F., 2012, An integrated watershed scale response to climate change for selected basins across the United States: U.S. Geological Survey Scientific Investigations Report 2011-5077, 142 p.

Markstrom, S.L., Niswonger, R.G., Regan, R.S., Prudic, D.E., and Barlow, P.M., 2008, GSFLOW-Coupled Ground-water and surface-water flow model based on the integration of the Precipitation-Runoff Modeling System (PRMS) and the modular ground-water flow model (MODFLOW-2005): U.S. Geological Survey Techniques and Methods 6-D1, 240 p.

Pint, C.D., 2002, A groundwater flow model of the Trout Lake Basin, Wisconsin: Calibration and lake capture zone analysis: M.S. thesis, Department of Geology and Geophysics, University of Wisconsin-Madison, $123 \mathrm{p}$.

Walker, J.F., and T.D., Bullen, 2000, Trout Lake, Wisconsin: A water, energy, and biogeochemical budgets program site: U.S. Geological Survey Fact Sheet 161-99, 4 p. 